\title{
News, Geography and Disadvantage: Mapping Newspaper Coverage of High-needs Neighbourhoods in Toronto, Canada
}

\author{
April Lindgren \\ School of Journalism \\ Ryerson University
}

\begin{abstract}
The quantity and subject matter of news coverage has been implicated in the success or failure of efforts to address social exclusion, poverty and other complex problems in disadvantaged city neighbourhoods. Using a methodology that combines traditional content analysis with computer-based mapping of geographic references in local news items, this study examines the Toronto Star newspaper's news coverage of 13 troubled neighbourhoods in Toronto, Canada. The results indicate that the paper is making only a limited contribution to the story-telling practices that are key to the development of neighbourhood engagement. It also suggests that media coverage may be a significant contributing factor to negative stereotyping that shapes internal and external opinions of the neighbourhoods. Both results have the potential to undermine strategies aimed at addressing problems such as social exclusion and poverty.
\end{abstract}

Keywords: news, social exclusion, stereotyping, neighbourhoods

Canadian Journal of Urban Research, Volume 18 Issue 1, pages 74-97.

Copyright (C) 2009 by the Institute of Urban Studies

All rights of reproduction in any form reserved.

ISSN: $1188-3774$ 
Résumé

Le contenu et la quantité des reportages d'actualités sont des facteurs important dans la résolution effective des problèmes d'exclusion sociale, de pauvreté et autres problèmes complexes qui sévissent dans les quartiers défavorisés des villes. Cette étude utilise une méthodologie qui combine l'analyse de données traditionnelle avec une corrélation informatique des références géographiques relevées dans les reportages d'actualités. L'étude analyse la couverture médiatique du Toronto Star sur 13 quartiers en difficculté de Toronto au Canada. Les résultats indiquent que le quotidien utilise de façon limitée les pratiques d'écriture qui influencent le développement de l'engagement communautaire. L'étude conclue que la couverture médiatique peut jouer un rôle important dans le stéréotypage négatif qui infuence les opinions sur les quartiers. Les résultats de l'étude démontrent un potentiel de nuire aux stratégies visant à résoudre les problèmes tels que l'exclusion sociale et la pauvreté.

Mots clés: reportages d'actualités, l'exclusion sociale, stéréotypage négatif

\section{Introduction}

News coverage has been implicated in the success or failure of efforts to address social exclusion, poverty and other complex problems in disadvantaged city neighbourhoods (Forrest and Kearns 2001; Friedland 2001; Wacquant 2008; Wassenberg 2004a, 2004b). This study analyzes the Toronto Star (print edition) newspaper's coverage of 13 geographically defined pockets of social need and poverty in Toronto, Ontario, that have been designated as "priority areas" (Strong Neighbourhoods Task Force 2005) for publicly funded social and infrastructure investments.

Using methodology that combines traditional content analysis with computer mapping of geographic references in local news items, data on the amount and type of news published about the priority areas in Canada's largest-circulation newspaper is analyzed to assess the Star's role in fostering local community engagement and democracy, its role in shaping perceptions of the priority areas and the extent to which the newspaper performs a watchdog role in terms of monitoring what is now a major anti-poverty initiative involving significant expenditures of public money and charitable funding.

\section{Context}

The City of Toronto, a hub of 2.5 million people at the centre of Canada's most populous metropolitan area, has long prided itself on being a city of strong neighbourhoods. In recent years, however, some neighbourhoods have fallen behind. In 2004, United Way Toronto highlighted this phenomenon in a report that raised 
Canadian Journal of Urban Research / Revue canadienne de recherche urbaine

concerns about geographic concentrations of poverty and a widening gap between rich and poor (United Way Toronto and the Canadian Council on Social Development 2004). Subsequent research by the city, United Way Toronto and a task force of civic leaders led to the identification of 13 designated "priority areas"characterized by rising poverty levels, high social needs and inadequate social services and infrastructure (Strong Neighbourhoods Task Force 2005). The difficulties faced by residents in these geographically defined pockets of need have been linked to the rising cost of living in Toronto, the disappearance of well-paid jobs and the difficulties that thousands of new immigrants encounter when they look for work. With many families gravitating to the cheapest available housing, the city has experienced a dramatic rise in poverty concentrations, particularly in the ring of inner suburbs surrounding the city core (Strong Neighbourhoods Task Force 2005).

The challenges facing the priority areas are compounded by the fact that these urban communities once catered to middle-income households and therefore lack the transit, local shopping and social services required to meet the needs of lowincome, socially marginalized newcomers (Strong Neighbourhoods Task Force 2005). These days, residents tend to include a higher than average number of atrisk populations including visible minorities, recent immigrants and single-parent families. The average low-income rate in the priority areas is 24.1 percent, higher than the city average of 19.4 percent. Eleven of the 13 areas have family median incomes (after tax) below the city average of $\$ 46,240$ (City of Toronto 2008).

\section{Figure 1.}

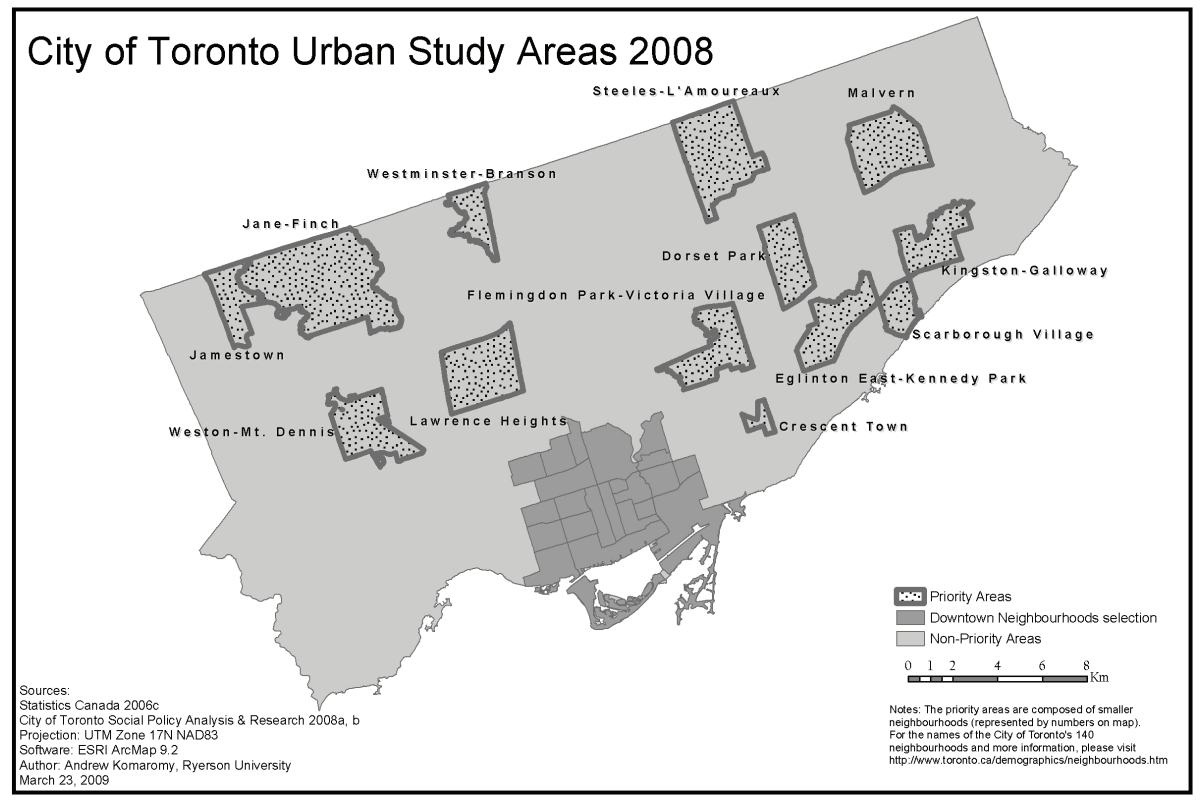


Since the priority areas were first identified in 2005-2006, governments and non-profit agencies have committed nearly $\$ 100$ million to geographically specific programs, services and infrastructure (Perchall 2009; City of Toronto 2009a, 2009b; Youth Challenge Fund 2008a, 2008b).

Consistent with recent research on place-based neighbourhood change strategies (Freiler 2004, 2006; Gorman 2006), these investments have been undertaken with two objectives in mind. The first is to bolster comprehensive, system-wide local services and infrastructure. The second is to encourage community engagement and resident-led neighbourhood governance so that the people who live in the priority areas can address and influence issues that are important to them (Strong Neighbourhoods Task Force 2005; Youth Challenge Fund 2008a). Community engagement can range from individuals simply taking an interest in an issue through to actively participating in a local group, association or political organization to influence matters of public concern. Swanson (2000), however, notes that all such activities presuppose citizens have access to the basic information required to debate local issues and take action.

One potential source of such information is the Toronto Star. Canada's largestcirculation daily newspaper-419,069 on weekdays and 608,001 on Saturdays (Trichur 2009)—reaches more adults than any other daily newspaper in the Toronto area's competitive news market (Toronto Star 2009). In contrast to more local, neighbourhood-based community publications, the Star considers the Greater Toronto Area, made up of the central city of Toronto and the four surrounding regions of Halton, Peel, Durham and York, to be its core circulation area (Toronto Star 2009a). Indeed, until recent design changes, the paper's masthead proclaimed the Star the "voice" of the Greater Toronto Area.

Above and beyond its newsgathering mandate, the newspaper's management adheres to a set of values known as the Atkinson principles, which include commitments to a strong, united, independent Canada, to social justice and individual and civil liberties, to community and civic engagement, to the rights of working people and to the idea that government has a role to play where public need is not being addressed (The Atkinson principles and the Toronto Star 2005).

The newspaper's claim to speak for all residents of the GTA, its dominant position in the Toronto news market, and its express goal of fostering social justice and community and civic engagement, made it an appropriate choice for this study.

\section{Neighbourhood Change Strategies and the Role of the Media}

Why does it matter how Toronto's priority areas are covered in the news? It matters because research suggests media outlets select and deliver information that feeds local action and engagement (Ball-Rokeach, Kim and Matei 2001; Forrest and Kearns 2001; Friedland 2001; Swanson 2000). It matters because research suggests news coverage can play a role in neighbourhood change by shaping how 
residents see themselves and how outsiders see troubled neighbourhoods (Kearns and Parkinson 2001; Wacquant 2008; Wassenberg 2004a, 2004b). And it matters because the media, in addition to being implicated as a factor in the success or failure of targeted neighbourhood change strategies, also has a watchdog function to fulfill in terms of monitoring a costly, high-stakes social experiment (Black 2009; Gorman 2006). This section explores the theoretical basis of these three reasons in more detail.

Theories of social capital underpin the notion that media coverage bolsters community engagement and shapes perceptions of community. Forrest and Kearns (2001), in their bid to move the concept of social capital out of the realm of the abstract, identified what they called domains of social capital including empowerment (where people feel listened to and involved in processes that affect them); participation (where people take part in social and community activities); associational activity (formation of formal and informal groups); support networks (where individuals and associations support each other); trust (of other residents and local organizations); and belonging (where residents feel connected to one another and have a sense of belonging to the place). These forms of social capital are often in short supply in poor neighbourhoods, they note, but can play an important role in their "regeneration" (p. 2139). Public policies that encourage the realization of these objectives, Forrest and Kearns (2001) suggest, include giving people a role in policy processes, establishing/supporting local activities, organizations and networks, and encouraging a sense of belonging by boosting the identity of places through urban design, street furnishings and naming.

This theory, now being translated into practice in Toronto's 13 priority areas, is reflected in the action plan articulated by the Strong Neighbourhoods Task force (2005), which insists the key to successful neighbourhoods is community participation where residents have "the capacity to lead, and the ability to make plans and identify neighbourhood priorities, based on sound knowledge of their communities" (p. 14).

News items are a key source of that "sound knowledge." McLeod, Scheufele and Moy (1999) found that newspapers in particular, play a central role in stimulating local political participation while Friedland (2001) contends that "democratic groups are more likely to form in communities that are integrated through communication" (p. 359). He describes a democratic vision whereby a critical mass of people, through access to information, become concerned about an issue, organize and thereby set a public agenda based on the problems they face. They participate in the identification of solutions that are then publicized so residents can monitor whether they are working.

Ball-Rokeach, Kim and Matei (2001) dug deeper into the media's role as a factor in community engagement by examining the neighbourhood "storytelling" that occurs in metropolitan (city-wide) media, in local neighbourhood media 
and among individual residents. In their investigation of the link between the role of multi-level storytelling and residents' sense of belonging and community engagement, they examined seven Los Angeles neighbourhoods and concluded that the existence of robust storytelling on all levels was a key factor in the communication process through which "people go from being occupants of a house to being members of a neighbourhood" (p. 394) with a stake in what happens to the community. Focus group participants in the Los Angeles study also indicated that they felt less inclined to engage in discussions (storytelling) about their neighbourhoods when the media ignored them or when the media, police and other institutional players told only negative stories about their communities. Those areas of the city that are covered by the media and are portrayed as "efficacious neighbourhoods have a distinct advantage over those that must create bottom-up processes of storytelling their neighourhood," the researchers concluded (p. 398).

As suggested earlier, news coverage of Toronto's priority areas also matters because it shapes how both non-residents and residents perceive communities and neighbourhood reputations. More precisely, the news media is rife with images and information that create a sense of different urban places for people who can't experience those places first-hand. As Parisi and Holcomb (1994) note, "The newspaper is a major instrument delivering a sense of the space beyond our senses. It evokes a world we inhabit largely through symbolic representation" (p. 377).

From the perspective of urban scholars, one practical implication of news coverage of distressed areas is that it can raise citywide awareness of neighbourhood problems, and fuel the political will to address those problems (Conway \& Konvitz 2000). At the same time, however, the symbolic representation of disadvantaged neighbourhoods in news media coverage can be sensationalist, negative and stereotypical, particularly when the communities are home to significant visible minority populations (Dunn 1998). These concerns were reflected in an Ontario study of the roots of youth violence (McMurtry \& Curling 2008), for instance, that highlighted local discontent about the negative media portrayal of disadvantaged communities, including four of Toronto's priority areas (KingstonGalloway, Jane-Finch, Jamestown and Steeles-L'Amoreaux). The consequences of this negative coverage, the report's authors suggested, are that whole communities are criminalized, that residents of the communities start believing the negative stereotypes, and that young people from those neighbourhoods lose out on jobs and other opportunities because of their "bad" addresses.

Research suggests such concerns are not unfounded. Wassenberg (2004a, 2004b) makes a distinction between the opinions and mental images of neighbourhoods formed by people within the community-residents, workers and business owners, for example-and external opinions and mental images held by people who may have never even been to the area. In his research on media coverage, stigma and Dutch housing estates, he highlights the media's role in 
shaping these external and internal neighbourhood images (Wassenberg 2004b). Communities where both the insiders and the outsiders hold negative images of a community are the most problematic, he contends, because "a bad image is both a result of and a cause for decay" (Wassenberg 2004b, 280). While it is difficult to pinpoint where and when problems begin, Wassenberg offers a scenario that starts with a neighbourhood where decent quality housing and public space begin to decline. This leads to lagging property values, high turnover rates of residents who are indifferent to and uninvolved in the community, and growing problems with crime, pollution and personal safety. The neighbourhood decline attracts media attention that focuses on crime, drug abuse and visible signs of decay including graffiti, vacant shops and troubled schools (Wassenberg 2004a, 2004b). People who do not live in the neighbourhood form negative images of the territory, he suggests. Friends and relatives might worry about visiting. Taxi drivers might refuse to come into the neighbourhood. Residents might find their addresses make it more difficult to land jobs.

Wassenberg and others have also observed that neighbourhood reputation can also affect the perceptions that residents of troubled areas have of themselves. The French-American sociologist Loic Wacquant (2008), for instance, compared urban poverty in Chicago and Paris and concluded that when people who live in troubled communities internalize what he calls "territorial stigmatization" (p. 174), it compounds local problems. Residents who believe they live in a "bad" area, Wacquant found, distance themselves from other residents, focus on moving away, and do not engage with other community members in attempting to address local issues. The result is a neighbourhood that lacks social ties and cohesion and is even more vulnerable to crime and other urban problems. Negative representations of the neighbourhood, he concluded, set off a "deadly self-fulfilling prophesy through which public taint and collective dishonour" (p. 184) fuel the very problems residents seek to escape.

Not all residents of stigmatized neighbourhoods, however, see their communities as something to be left behind as soon as possible. Kearns and Parkinson (2001) observed that some residents—in particular those for whom moving away is not an option-respond to discrimination and social exclusion by bonding with one another to "achieve subsistence and survival" (p. 2105). They note, however, that this response to social exclusion can be inward looking with residents more focused on surviving than on branching out and moving forward.

From a social capital perspective, therefore, the amount of news coverage of Toronto's priority neighbourhoods matters because information is an important determinant of community engagement and local democracy. The nature of the news coverage matters because it can play a role in geo-spatial stigmatization by both outsiders and neighbourhood residents themselves. This in turn can undermine social cohesion, exacerbate problems and generate a siege mentality among 
beleaguered residents to the point where they stop looking for opportunities beyond their neighbourhood boundaries.

The final reason news coverage of the priority areas matters has to do with the watchdog role of the media, or as Kovach and Rosenstiel (2007) put it, the media's obligation "to monitor power and offer voice to the voiceless" (p.139). Friedland (2001) makes this point in the local context when he says the media has a role in publicizing solutions put in place to address community problems as well as in monitoring whether those solutions are working. This is particularly applicable to Toronto's neighbourhood change initiative in the priority areas because, as Gorman (2006) observes, "there are great difficulties in evaluating the impact of neighbourhood strengthening efforts. Strong, empirical data linking the mechanics of investing in place with resident level outcomes do not exist" (p. 10). In the absence of formal methods of determining whether the priority-area investments are having an impact, news media have a role to play at least in seeking out anecdotal evidence, in monitoring how the considerable resources devoted to the strategy are being invested and in ensuring authorities are accountable for the funds. To the extent that allocating scarce resources to relatively few neighbourhoods is becoming an ever more popular poverty-fighting strategy (Black 2009) there are also valid questions to be asked about the availability of services for high-needs residents who do not happen to live in the targeted communities.

\section{Methodology}

This investigation of the Toronto Star's coverage of Toronto's 13 priority areas combines two research approaches. First, a content analysis of articles and photographs was conducted by reading printed copies of the Toronto Star to generate data on the amount of local news coverage and its subject matter. Content analysis was also used to identify spatial/geographic references in each local item. ArcGIS - an information system that uses hardware and software to store, retrieve, map and analyze geographic data-was then employed to translate the spatial references into news maps. Information visualization in this form allows investigators to view, understand and interpret large sets of data in a variety of ways and facilitates the identification of relationships and patterns (Card, Mackinley and Schneiderman 1999).

Both the content analysis and the geospatial data were derived from 28 issues of the Toronto Star published between Jan. 7, 2008 and Aug. 23, 2008. Constructed week sampling (Monday from the first week, Tuesday from the next week, Wednesday from the third week, etc.) ensured that content from different days was examined and that no major news event was overrepresented. Research on content analysis suggests that two constructed weeks are adequate to produce reliable data that is representative of a full year (Riffe, Aust and Lacy 1993). This 
Canadian Journal of Urban Research / Revue canadienne de recherche urbaine

study examined four weeks over an eight-month period to ensure the sample size was sufficient.

The first step in the analysis of each newspaper issue involved the coders reading hard copies of the publication to determine the total number of articles and photographs, as well as the total number of local articles and photographs. Local items were defined as articles and photographs that dealt primarily with local events, people, issues and places in the Greater Toronto Area. Each local item was then coded according to one of the general subject categories outlined in Table 1 .

\section{Table 1.}

\section{Article/Photograph Subject Categories}

\begin{tabular}{|l|l|}
\hline PO & Police/crime/legal/courts/local/local public safety \\
\hline ED & Education \\
\hline HE & Health/health protection/medical \\
\hline TR & Transit/gridlock/sprawl/traffic \\
\hline SO & Social supports/affordable housing/poverty/social justice \\
\hline LU & Land use/urban design/development/redevelopment \\
\hline MU & Municipal politics/services/budget \\
\hline EW & Environment/weather \\
\hline FA & Fire/accident \\
\hline RI & Religious-cultural diversity/multiculturalism/immigration \\
\hline AE & Arts/entertainment/local attractions \\
\hline BU & Business \\
\hline SP & Sports \\
\hline NS & $\begin{array}{l}\text { Local impact of national security/terrorism/foreign policy/ } \\
\text { foreign disasters/human rights/casualties }\end{array}$ \\
\hline FP & Federal or provincial politics/initiatives - local angle \\
\hline OT & Other/pets/travel/human interest \\
\hline
\end{tabular}

Local articles and photographs were further classified according to item subject detail (a more detailed coding category), whether a particular ethnic or religious group was referenced in the article or photo, the location of the item in the paper, article length and the news item's form (news story, photograph, column, editorial, review, letter or item submitted by readers).

The geospatial aspect of the research involved identifying every spatial reference in each local item and entering each reference into the database. The references included: 
- all explicit mentions of specific places in articles and photo cutlines.

- the address of each source quoted where the source was explicitly associated with a residence, business or organization.

- neighbourhoods as defined by the City of Toronto (City of Toronto 2007) or general areas of the city when they were explicitly mentioned.

Each geographic reference was then mapped using ArcGIS software that assigned points to specific map locations. In cases where general areas such as neighbourhoods, entire cities or the GTA as a whole were referenced, polygons were used to represent these spaces. Seven geospatial references, for example, were entered into the database for a June 17, 2008 Toronto Star story (Lu 2008) dealing with the introduction of a breakfast program at schools in the Jane-Finch priority area. The geospatial news map generated from this data (Figure 2) uses a large, light-coloured polygon to represent the story's general reference to Toronto as a whole and a second darker-coloured polygon to represent a reference to the JaneFinch area of the city. Points (flags) are used to represent each of the three schools mentioned in the story. The Toronto District School Board headquarters and city hall are both represented on the map by dots because officials from both institutions were quoted in the story.

\section{Figure 2.}

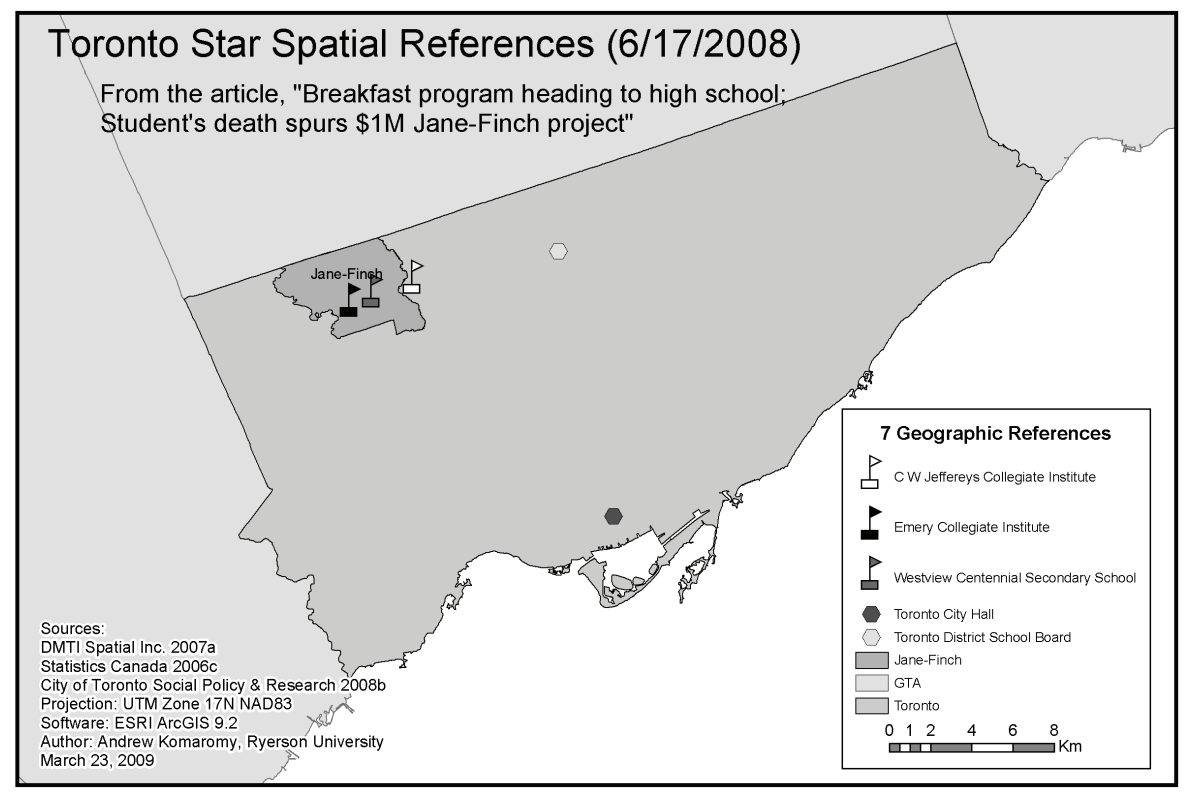


ArcGIS mapping software was used to generate individual news maps similar to Figure 2 for every local news item (articles and photographs) that mentioned a location in the City of Toronto. Items that mentioned only locations in the four surrounding regions were excluded from this analysis because the placebased social policy for the priority areas is unique to Toronto. The individual news maps were then combined to generate a dot density map that shows all spatial references to the city locations contained in local news items. (To simplify the maps, polygons and lines are not shown although they are used in the data analysis). Finally, the data represented on the Toronto map were sorted according to three distinct geographic categories (study areas) for purposes of comparison. Based on subsets of the city's 140 officially designated neighbourhoods (City of Toronto 2007), these geographic study areas were:

- the 13 priority areas. They encompass 22 city-designated neighbourhoods with a total population of 483,321 (City of Toronto 2007).

- the downtown core. Since the priority areas consist of 22 neighbourhoods, a grouping of 22 neighbourhoods in the city's downtown was selected as representative of the city core for the purposes of this study. Total population for the 22 downtown neighbourhoods is 334,985 (City of Toronto 2007).

- the non-priority neighbourhoods. This area represents the remaining 96 city-designated neighbourhoods in the ring around the city centre. Total population of this area is $1,684,975$ (City of Toronto 2007).

Each dot on the Toronto map linked to the news item that mentioned that particular location. This made it possible to generate a list of news articles and photographs associated with each of the three geographic study areas. The same news item can appear on all three lists if it contains spatial references in each of the three geographic areas. The Jane-Finch article mapped in Figure 2 is an example of one such item that would appear on the news item list for each of the three study areas because it contains geographic references to locations in the downtown (city hall), the non-priority neighbourhoods (Toronto District School Board headquarters) and the Jane-Finch priority area (high schools.)

News items that did not contain a specific reference to any of the three study areas were excluded from the analysis. A story, for instance, that contained only a general reference to a "Toronto man," or "Yonge Street" (which starts in the city centre and runs northward deep into rural Ontario) would not be included on any of the lists. 
It should also be noted that:

- Spatial references associated with photographs were only added to the database if the photograph's cutline information identified the place featured in the image. This means, for instance, no geographic references were entered for headshots of people where their name was the only information accompanying the photograph. By comparison, a geographic reference was added to the database and would show up as a dot on maps if a photograph of workers leaving a factory included accompanying information naming the factory.

- A dot, line or polygon may link to just one article or photograph if, for instance, it was the only news item to mention the location. In many cases, however, each location links to many different news items because the location is referenced in numerous stories and photos.

Coding of the 28 issues was conducted by the principal investigator, who was responsible for 10 issues, and a research assistant, who coded 18 issues. After training, a full intercoder reliability test was conducted based on the standards and guidelines outlined by Lombard, Snyder-Duch and Campanella Bracken (2002).

Four randomly selected issues of the 28 were used in the test. There were 410 local items in the test sample out of a total 2,731 stories and photographs identified as local to the Greater Toronto Area. There were 756 geographic references out of a total of 5,697. As such, the test sample represented more than 10 percent of the data.

Intercoder reliability for interval variables such as the number of local articles and photographs was calculated using Lin's concordance. Reliability was considered acceptable at or above .700. Across the four test issues, the Lin's concordance coefficient was at or above .750 for all item count variables, with the exception of four variables where there were five or fewer items in each category. These were eliminated from the analysis and discussion.

Intercoder reliability for nominal variables such as the subject matter of each news item was measured using Cohen's kappa, a relatively conservative index (Lombard, Snyder-Duch \& Campanella Bracken 2002). Reliability was considered acceptable at or above .700 .

At the item level, intercoder reliability was at or above .766 for all variables with one exception. This variable was eliminated from the analysis and discussion. In the case of geographic references, the Lin's concordance coefficient for the number of references was .950 , while the Cohen's kappa coefficient for the geographic references themselves was .840 .

Prior to incorporating the four test issues into the full, 28-issue sample, disagreements that surfaced during the coding test were resolved through discussion 
Canadian Journal of Urban Research / Revue canadienne de recherche urbaine

and, where necessary, clarification of the coding guide. Additional details of the coding instruments, procedures and instructions are available from the author.

\section{Results}

\section{Quantity of priority-area news coverage}

The first step in determining the amount of priority-area news coverage published in the Toronto Star was to visually explore the data by selecting all news items with geographic references in Toronto and generating a dot-density map (Figure 3 ). The image reveals relatively few geospatial references to locations in the priority neighbourhoods and non-priority neighbourhoods compared with the downtown core.

\section{Figure 3.}

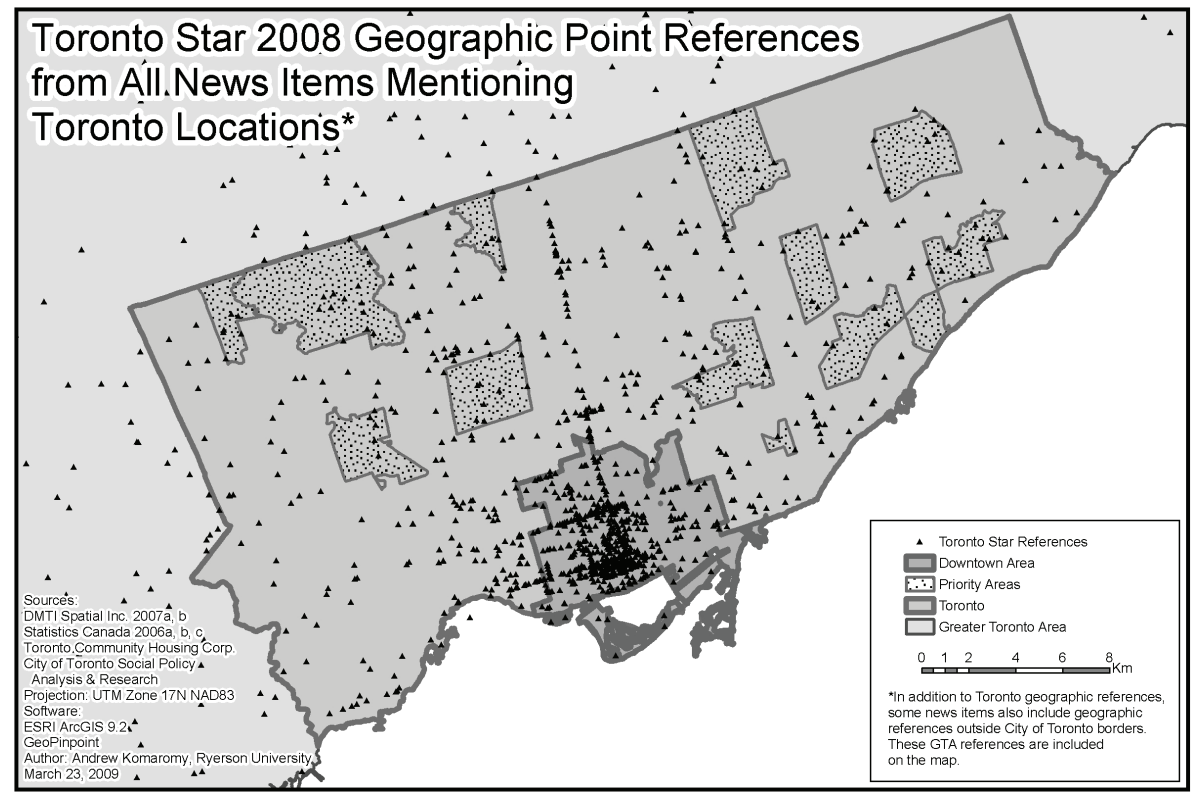

The story of highly differentiated amounts of news coverage by geographic area also emerges from a more detailed analysis of the data. The spatial references on the City of Toronto map linked to a total of 1,737 individual news items (articles and photographs). When this was broken down, spatial references in the downtown study area linked to 1,249 articles and photographs. Spatial references in the non-priority neighbourhoods linked to 650 articles and photographs while spatial references in the priority areas linked to only 122 news items. The total number of news items for the three study areas is greater than for the City of Toronto as a whole because some news items contain references to locations in more than one study area. 
For the purposes of comparison, the number of news items per official citydesignated neighbourhood was calculated for each study area. The results show there were 56.8 news items per downtown neighbourhood, 5.5 news items per priority-area neighbourhood, and 6.8 news items per neighbourhood in the nonpriority areas (Figure 4).

\section{Figure 4.}

\section{News items per neighbourhood}

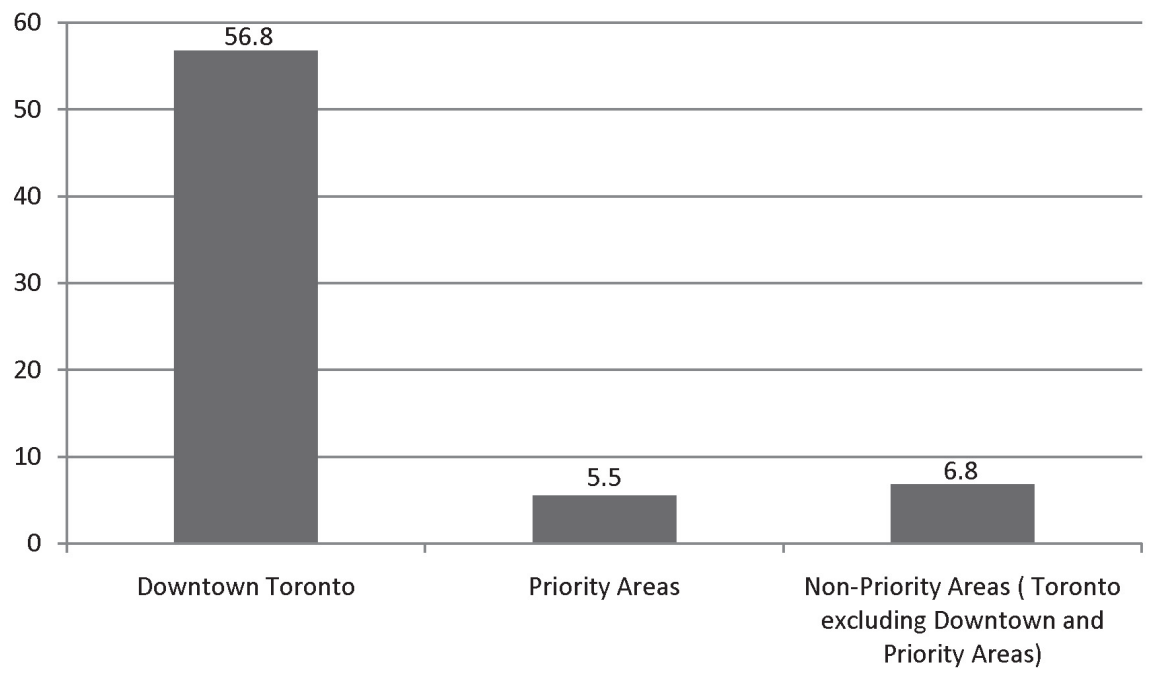

The data were also examined on a per capita basis (Figure 5), an approach that recognizes population differences in the three study areas. In the downtown, for instance, there were 2.59 news items per capita compared to .37 news items per capita in the priority areas and .39 in the non-priority neighbourhoods.

\section{Nature of the Priority-area News Coverage}

The data also reveal major differences in the type of news coverage characterizing each urban study area (Figure 6). Most notably, sports and arts and entertainment topics dominated news coverage in the downtown core, together accounting for 38.4 percent of all downtown coverage. Police-related topics, however, were by far the most common subject matter (31.15 percent) dealt with in news items that mentioned locations in the priority areas. By comparison, police-related news items represented 11.3 percent of news coverage in the downtown area and 15.5 percent in the non-priority neighbourhoods.

Further analysis of police-related news items in the priority areas suggests that they dealt extensively with bad news in terms of neighbourhood quality of life. 
Canadian Journal of Urban Research / Revue canadienne de recherche urbaine

Stories about serious crime and traffic-related crime, for instance, accounted for more than 70 percent of news items that were coded as police-related (Figure 7).

Figure 5 .

\section{News items per capita(1000 people)}

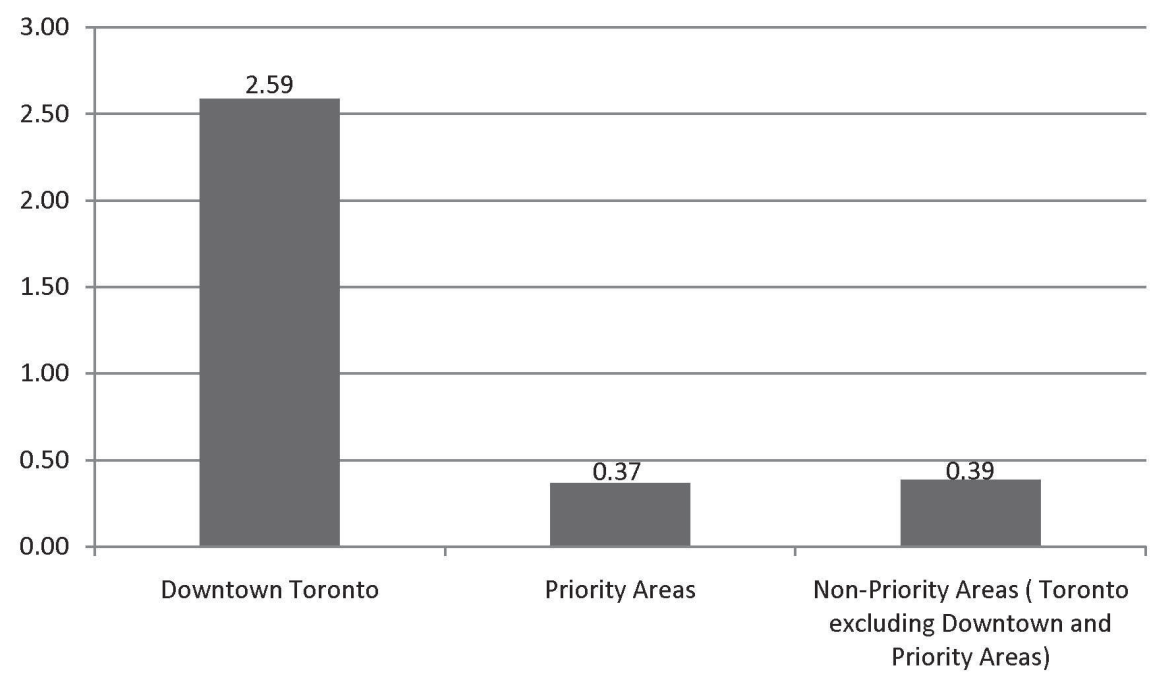

Figure 6.

Percentage of Items in $\mathbf{3}$ Study Areas by Subject

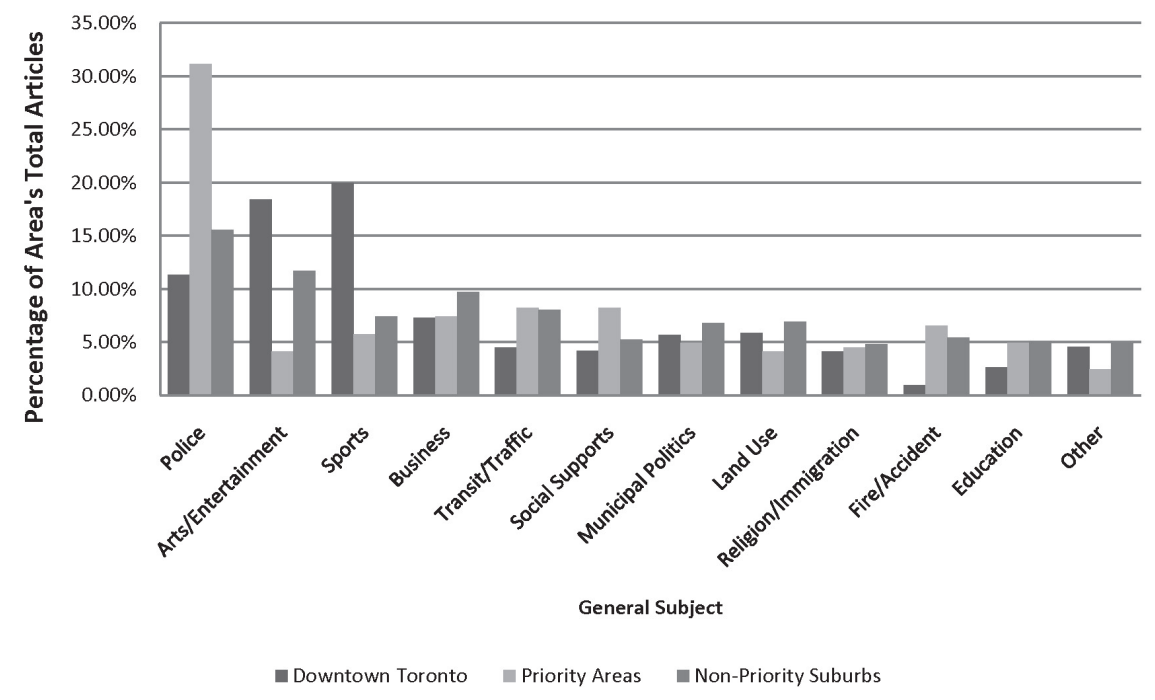


Figure 7.

\section{Breakdown of 38 Police/Crime-Related News Items in the}

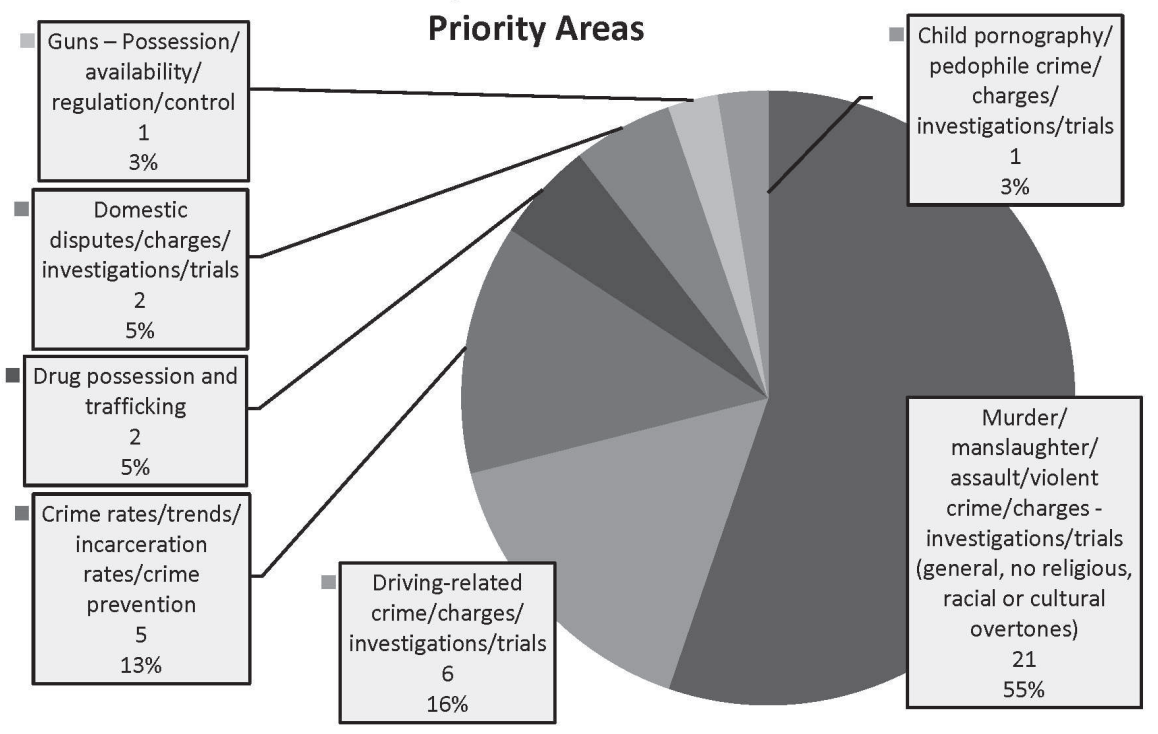

\section{Analysis/discussion}

The first significant finding is that the Toronto Star's news coverage of the priority areas and the surrounding non-priority neighbourhoods is much less extensive than coverage of the downtown core.

Phyllis Kaniss, in Making Local News (1991), offers a number of explanations for the concentration of news coverage in the city centre. She argues, for instance, that media outlets faced with the need to appeal to widely dispersed and diverse audiences in a sprawling metropolitan area aim to attract audiences by promoting common symbols that generate a sense of place for both downtown and suburban readers. The data from this study suggest that symbolic place-making may be a factor in explaining the Star's preoccupation with coverage of downtown professional sports in particular. Indeed the major downtown sports venues that are home to Toronto's professional baseball, football and hockey teams were among the most often-cited geographical references in the newspaper's local coverage (Figure 8).

Kaniss also points to newsgathering practices as factors that explain the concentration of downtown coverage. Reporters and editors who work for media outlets located in the downtown (where the Toronto Star newsroom is situated), she noted, are better placed to observe and report on what's happening in the city centre than in distant suburbs. 
Figure 8.

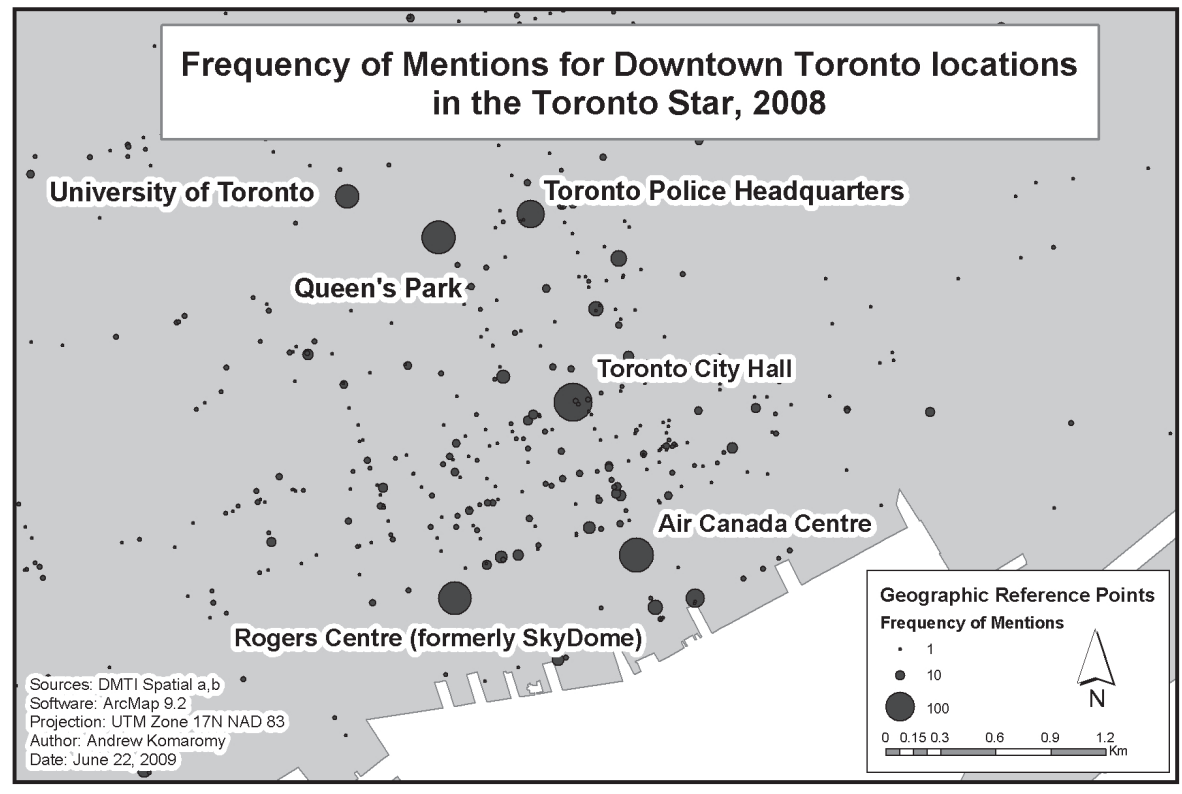

Other research has consistently shown that news is dominated by official sources because they are reliable and easily accessed (Gans 1979; Kaniss 1991; Schudson 1989). Consistent with such findings, major institutions—all of them concentrated in the downtown-were indeed the geographical references cited most often in the Toronto Star's local news coverage. (Figure 8). Toronto city hall, with 190 geographic references, was the most commonly mapped spatial reference during the January to August 2008 study period followed by the provincial legislature at Queen's Park (166 references). Two professional sports venues (the Air Canada Centre and the Rogers Centre) were next on the list with 153 and 141 mentions respectively followed by Toronto Police headquarters, which appeared 103 times in the geographic references data set.

The tendency to extensively cover institutions that facilitate newsgathering by orchestrating news conferences, operating media relations departments and making sources readily available was likely compounded by the presence of Toronto Star news bureaus at city hall, Queen's Park and police headquarters. While the bureau reporters extensively covered those downtown institutions and events, no bureaus provided similar day-to-day coverage in the outlying areas (Hepbourn 2009). Reporters weren't on the ground daily anywhere beyond the city core cultivating contacts, observing first-hand what is going on and providing ongoing news coverage. As a result, during the 28-day sample, only 122 news items referencing the priority areas appeared in the Star and nearly one-third or 38 of them 
were police and crime-related. Given the challenges faced by these neighbourhoods and the magnitude of the public and charitable investments being made in their future, this amounts to relatively thin coverage of the priority areas and suggests that the Star is playing only a limited watchdog role in terms of monitoring a major public policy initiative.

This conclusion is reinforced by data that raise questions about the extent to which the Star provided priority area residents with access to information required for local democratic participation. While police and crime-related news accounted for 38 of the 122 news items, there were only 10 transit-related news items, 10 items related to social supports, affordable housing and poverty issues, nine business-related items, eight stories/photographs related to fire and accidents, seven news items dealing with sports and another seven dealing with health-related issues. There were six items in the categories of education and municipal politics respectively, and five or fewer news items in each of the remaining subject categories of land use, arts and entertainment, religious-cultural diversity, environment-weather, national security and "other." Over a four-week period, the overall picture is one of a limited supply of information about what is actually going on in neighbourhoods-information that community change advocates argue is required to foster civic engagement.

The study's other major finding is that news about the priority areas is dominated by negative subject matter while, by comparison, news items about sports and arts and entertainment are the mainstay of downtown news coverage. To assess whether the high degree of police-related news in the priority areas reflects higher neighbourhood crime rates, Toronto Police Service data on violence-related callsfor-service (CFS) were used as an indicator (Toronto Police Service 2008b). Calls of this sort relate to homicides, shootings, stabbing, wounding, person with a gun, person with a knife, sound of gunshot, robberies, sexual assaults, fights, assaults in progress, assaults just occurred and assistance for a police constable. Each neighbourhood was categorized according to the number of violence-related calls for service that originated in it between January and August 2008. Neighbourhoods that were the source of 185 to 415 violence-related calls for service were placed in the high-crime rate category while those with 83 to 184 calls were categorized as having medium crime rates. Low crime-rate neighbourhoods were defined as those that generated 7 to 82 violence-related calls for police service during the period examined for this study.

The results (Figure 9) indicate that in fact the highest volume of violence-related calls for service occurred in five neighbourhoods located in the downtown core. By comparison, the volume of calls for service in the neighbourhoods that make up the priority areas all fell into the low- to-medium range. This suggests these areas, despite the high proportion of police-related news coverage, actually experience lower crime rates than downtown city neighbourhoods. 
Figure 9.

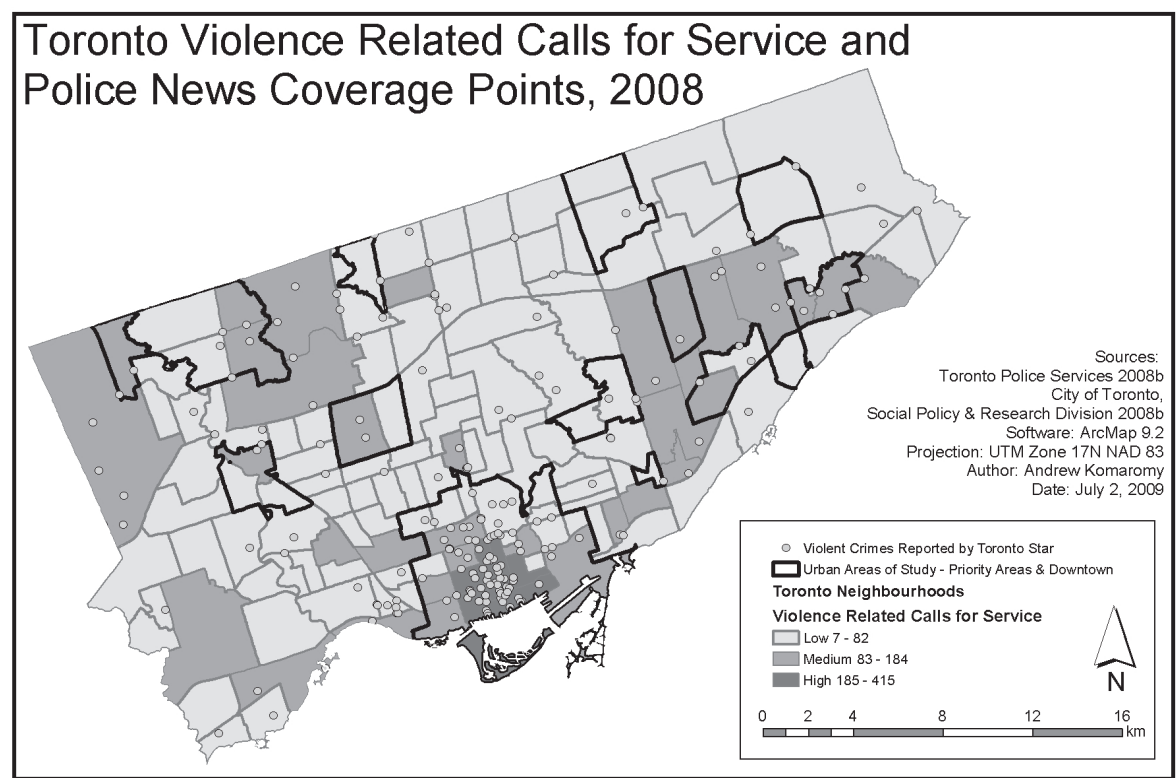

Newsgathering practices provide insight into the disconnect between the preoccupation with police/crime news coverage and the crime-rate indicator. The existence of a Star bureau at police headquarters combined with the monitoring of police communications that takes place in the Toronto Star newsroom suggests that police/crime news is relatively easy to come by. Police beat reporters pick up local crime stories through sources at police headquarters. Reporters in the newsroom monitor police radio communications and make regular telephone calls to police headquarters to collect the latest news. The result is a steady flow of crimerelated stories. The data do not reveal whether police have a propensity to highlight trouble in the priority areas when a reporter calls in and asks "what's new?" And no conclusions can be drawn at this point on whether reporters are more inclined to write stories about crime committed in neighbourhoods they themselves may perceive to be dangerous. What is evident is that police/crime news related to the priority areas is easily obtained by journalists while stories about other topics that require significant investments of time, effort and resources are done much less frequently. This dynamic - ready access to crime news and limited commitment to coverage of other topics-means that crime news dominates coverage of the priority areas even though indicators suggest other parts of the city face more serious problems with violent criminal incidents.

This pattern of news coverage has consequences. Anecdotal evidence suggests, for instance, that the emphasis on police/crime coverage in the priority areas may be linked to geographic stigmatization. In 2007, for instance, a young black uni- 
versity student from Malvern, a troubled east-end Toronto neighbourhood that has been designated a priority area, received a copy of an e-mail mistakenly sent to him by the person dealing with his application for a job with the provincial government. "This is the ghetto dude that I spoke to before," the message said (Diebel 2007). In early 2009, a local real estate agent praised a city councillor's efforts to rename the Jane-Finch community (another priority area) University Heights to reflect a large university in the vicinity. "It's a good thing... because the current name has negative connotations," the real estate agent said even as many incensed community residents insisted they were just fine with the old Jane-Finch designation (Aveling 2009).

\section{Conclusion}

Four years after governments and social service agencies began investing heavily in community programs, training and neighbourhood infrastructure, there is little official data available on the extent to which life has changed or improved for residents of the priority areas. This study illustrates that the Star has played only a limited role in monitoring the effects of the neighbourhood change strategy and in holding the public officials involved accountable for results. Inspired by the Atkinson principles (The Atkinson principles and the Toronto Star 2005), however, the newspaper is ideally placed to track value for money in the case of these priority-area investments, to chase down official assessments of the initiative to date or to report that so far at least, it's unclear whether the money allocated for the strategy is making a difference.

At the same time, the Star's limited role in local storytelling about the priority areas means it is only of limited use in providing residents with information that will help them identify issues and priorities. Hindered by this lack of knowledge, residents are inadequately equipped to lead or advocate change. The newspaper, meanwhile, is likely missing stories that may well be of interest to the broader community.

The Star's coverage of the priority areas also has implications for the success or failure of the neighbourhood change strategy in that the news items published in the paper have the power to shape internal and external perceptions of those neighbourhoods. The negative stereotyping fostered by the high-proportion of crime-related articles that characterizes news coverage of the priority areas can potentially undermine residents' willingness to become engaged in their "loser" communities and/or reinforce the desire of those whose prospects do improve to move away as soon as they are able.

These findings suggest a number of directions for future investigation that will advance our understanding of the role of news coverage in the outcome of a major urban anti-poverty strategy. The data raise questions about whether journalists' 
Canadian Journal of Urban Research / Revue canadienne de recherche urbaine

own negative perceptions of neighbourhoods lead them to reinforce stereotypes. Police data on calls about violent incidents during the period of time examined in this study indicated there is little or no difference in the crime rates between the priority areas and the non-priority neighbourhoods. Yet police-related stories accounted for a higher proportion of news items from the priority areas $(31.15$ percent of all items) than they did in the non-priority areas (15.5 percent of news items). This suggests there is room for additional investigation of reporters' perceptions of neighbourhoods and how those perceptions might influence their news judgment.

The role of the media in defining the reputation of disadvantaged areas also merits further exploration. Does perception of a distressed neighborhood vary according to the type of news media residents and non-residents consume? Finally, the results of surveys that measure the level of community engagement in the priority areas as well as residents' news consumption patterns need to be examined in conjunction with the results of neighbourhood change initiatives to probe in more detail the ways in which these variables are intertwined.

\section{Acknowledgements}

This research was made possible by generous financial support from Ryerson University and the Social Sciences and Humanities Research Council. I would also like to thank research assistant Andrew Komaromy for his work on GIS analysis and coding system design. Connie Fan's contribution as a research assistant and statistical analyst was invaluable. Harvey Low at the City of Toronto's Social Policy Analysis and Research Division, the University of Toronto's Cities Centre and the Toronto Police Service generously provided both advice and geographic data sets. Ryerson University's Abby Goodrum, Joyce Smith, Ivor Shapiro and Gene Allen offered valuable guidance and support.

\section{References}

Aveling, Nick. 2009. Area now being called University Heights, but some call change a rejection of how far we've come. Toronto Star, January 8: A10.

Ball-Rokeach, Sandra J., Yong-Chan Kim, and Sorin Matei. 2001. Storytelling neighbourhood: Paths to belonging in diverse urban environments. Communication Research 28: 392-428.

Black, Simon. 2009. Does Harlem have a lesson for Toronto neighourhoods? Toronto Star, March 15: A15.

Card, Stuart K., Jock D. Mackinley, and Ben Schneiderman. 1999. Information visualization: Using vision to think. San Francisco: Morgan Kaufmann.

City of Toronto. 2007, December. Toronto Neighbourhood profiles. http://www.toronto. ca/demographics/profiles_map_and_index.htm (accessed February 23, 2009). 
2008. Backgrounder: Social risk factors in priority areas 2008. http://www. toronto.ca/demographics/priorityareas.htm (accessed February 20, 2008).

2009a. Backgrounder: Proposed project model and implementation plan for youth gang prevention pilot project. January 22. http://www.toronto.ca/legdocs/ mmis/2009/cd/bgrd/backgroundfile-18639.pdf (accessed July 4, 2009)

2009b. 2009 Budget briefing note: Meeting the city's commitment to priority neighbourhoods, The Partnership Opportunities Legacy POL Fund. http://www. toronto.ca/budget2009/pdf/cap_budget_pdfs/BN_POL_\%20Fund.pdf (accessed February 28, 2009).

City of Toronto Planning Division, Policy and Research Section. 2008. City of Toronto Six Pre-amalgamated Regions: Boundaries [digital resource: vector].

City of Toronto, Social Policy Analysis \& Research Division. 2008a. City of Toronto Neighbourhoods 2008: Boundaries [digital resource: vector].

— 2008b. City of Toronto Priority Areas 2008: Boundaries [digital resource: vector].

Diebel, Linda. 2007. 'Ghetto dude' email sent by mistake: province. Toronto Star, July 21: A3.

Conway, Maureen and Josef Konvitz. 2000. Meeting the challenge of distressed neighbourhood. Urban Studies 37(4): 749-774.

DMTI Spatial Inc. 2007a. CanMap RouteLogistics 2007.3 Greater Toronto Area. Vers. 2007.3. Ryerson Map \& Data Resources: Geography [digital resource: vector].

— 2007b. GeoPinpoint 6.4. Ryerson Map \& Data Resources: Postal Geography [digital resource: vector].

Dunn, Kevin. 1998. Rethinking ethnic concentration: The case of Cabramatta, Sydney. Urban Studies 35(3):503-527.

Elections Canada. 2005. Federal Electoral Districts, 2005: Boundaries [digital resource: vector].

Environment Systems and Research Institute, Inc. 2003. Ontario Rivers 2003. Ryerson Map \& Data Resources: Drainage [digital resource: vector]. https://www. runner.ryerson.ca/madar//geospatial/libdata/action2b.cfm?ResourceID=132 (accessed June 24, 2008).

Forrest, Ray and Ade Kearns. 2001. Social cohesion, social capital and the neighbourhood. Urban Studies 38: 2125-2143.

Freiler, Christa. 2004. Why strong neighbourhoods matter: Implications for policy and practice. Strong Neighbourhoods Task Force. http://74.125.95.132/ search?q=cache:XL2noJu_194J:www.urbancentre.utoronto.ca/pdfs/curp/ SNTF_Why-Neighbourhoods-Mat.pdf+Christa+Freiler+\%22Why+strong+n eighbourhoods+matter\%22\&cd=1\&hl=en\&ct=clnk\&gl=ca (accessed March 13, 2009).

— 2006. Action for neighbourhood change: Toronto's Scarborough Village, Key learnings and implications for practice. Neighbourhood Engagement Initiative, 
Canadian Journal of Urban Research / Revue canadienne de recherche urbaine

Toronto: United Way of Greater Toronto.

Friedland, Lewis A. 2001. Communication, community, and democracy. Communication Research 28 (4): 358-391.

Gans, Herbert J. 1979. Deciding what's news: A study of CBS evening news, NBC Nightly News, Newsweek, and Time. New York: Pantheon Books.

Gorman, Cheryl. 2006. Orienteering over new ground: A neighbourhood theory of change. Ottawa: Caledon Institute of Social Policy.

Hepbourn, Bob. 2009. Toronto Star personal communication. June 17.

Kaniss, Phyllis C. 1991. Making local news. Chicago: Univ. of Chicago Press.

Kearns, Ade and Michael Parkinson. 2001. The significance of neighbourhood. Urban Affairs 38: 2103-2110.

Kovach, Bill and Tom Rosentiel. 2007. The elements of journalism: What newspeople should know and the public should expect. New York, NY: Three Rivers Press.

Local Health Integration Network. 2005. South East Local Health Integration Network Boundaries 2005: Boundaries [digital resource: vector].

Lombard, Matthew, Jennifer Snyder-Duch, and Cheryl Campanella Bracken. 2002. Content analysis in mass communication: Assessment and reporting of intercoder reliability. Human Communication Research 28: 587-604.

Lu, Vanessa. 2008. Breakfast program heading to high school; Student's death spurs \$1M Jane-Finch project. Toronto Star, June 17: A6.

McLeod, Jack, Dietram Scheufele and Patricia Moy. 1999. Community, communication, and participation: The role of mass media and interpersonal discussion in local political participation. Political Communication 16: 315-336.

McMurty, Roy, and Alvin Curling. 2008. The review of the roots of youth violence: Community perspectives report. Toronto: Queen's Printer. http://www. rootsofyouthviolence.on.ca/english/reports.asp (accessed March 2, 2009.)

Ontario Geospatial Data Exchange Administrator. n.d. Oak Ridges Moraine: Boundaries [digital resource: vector].

Ontario Ministry of Municipal Affairs and Housing. 2005. TTC \& GO Transit Data 2005: Routes [digital resource: vector].).

Ontario Ministry of Natural Resources. 2005. Greenbelt Natural Heritage System, 2005: Boundaries [digital resource: vector]

Parisi, Peter, and Briavel Holcomb. 1993. Symbolizing place: Journalistic narratives of the city. Journalism Quarterly 70: 133-139.

Perchall, Scott. 2009. United Way Toronto personal communication. February 17.

Riffe, Daniel, Charles F. Aust, and Stephen Lacy. 1993. The effectiveness of random, consecutive day, and constructed week sampling. Journalism Quarterly 70: 133-139.

Schudson, Michael. 1989. The sociology of news production. Media, Culture and Society 11: 263-282.

Statistics Canada. 2006a. GTA Boundary, 2006: Boundaries [digital resource: 
vector].

2006b. GTA county boundaries, 2006: Boundaries [digital resource: vector].

2006c. GTA Municipal boundaries, 2006: Boundaries [digital resource: vector].

Strong Neighbourhoods Task Force. 2005. Strong neighbourhoods: A call to action. http://74.125.95.132/search?q=cache:CWJOdTD3zmsJ:www.toronto.ca/ demographics/sntf.htm+Toronto+United+Way+\%22Strong+Neighbourhoods +Task+Force\%22\&cd=4\&hl=en\&ct=clnk\&gl=ca (accessed March 24, 2009).

Swanson, David L. 2000. The homologous evolution of political communication and civic engagement: Good news, bad news, and no news. Political Communication 17(4): 409-414.

The Atkinson principles and the Toronto Star. 2005. http://www.thestar.com/ aboutUs/atkinson (accessed February 23, 2009).

Toronto Community Housing Corp. 2008. TCHC Housing developments with over 6 units: Postal geography [digital resource: vector].

Toronto Police Service. 2008a. Toronto Police Divisions: Boundaries [digital resource: vector].

— 2008b. Violent Calls For Service by Neighbourhood: January-August. Postal Geography [digital resource: vector].

Toronto Star. 2009. Toronto Star Readership. http://mediakit.thestar.ca/details. asp?id=1\&subid=69 (accessed Jan. 3, 2010)

Toronto Star. 2009a. Toronto Star Sections. http://mediakit.thestar.ca/details. asp?id=1\&subid=30 (accessed Jan. 3, 2010)

Trichur, Rita. 2009. The Star stable in tough market. Toronto Star, March 26: B3.

United Way Toronto and the Canadian Council on Social Development. 2004. Poverty by postal code: The geography of neighbourhood poverty, 1981-2001. http://unitedwaytoronto.com/whatWeDo/reports/povertyByPostalCode.php (accessed March 23, 2009).

Univ. of Toronto, Cities Centre. 2005. Average individual income in six categories by census tracts, 2005: Census [digital resource: vector].

Wacquant, Loïc. 2008. Urban outcasts: A comparative sociology of advanced marginality. Cambridge: Polity Press.

Wassenberg, Frank. 2004a. Large social housing estates: From stigma to demolition? Journal of Housing and the Build Environment 19: 223-232.

_ 2004b. Renewing stigmatised estates in the Netherlands: A framework for image renewal strategies. Journal of Housing and the Built Environment 19: 271-292.

Youth Challenge Fund. 2008a. What we do. http://youthchallengefund.org/index. php/pages/what-we-do (accessed February 23, 2009).

2008b. Youth Challenge Fund fact sheets. http://youthchallengefund.org/ index.php/pages/fact-sheets (accessed February 19, 2008). 